\title{
PERSEPSI MAHASISWA TERHADAP LKM GEOMETRI TRANSFORMASI BERBASIS DISCOVERY LEARNING DENGAN PENDEKATAN KONTEKSTUAL
}

\author{
Kenys Fadhilah Zamzam, Siti Napfiah, Asri Putri Anugraini \\ IKIP Budi Utomo Malang \\ kenysfz@gmail.com
}

\begin{abstract}
Abstrak
Persepsi merupakan penafsiran secara konkrit dan nyata dari masingmasing orang dalam memandang sesuatu. Pada penelitian ini, objek yang diamati adalah Lembar Kerja Mahasiswa (LKM). LKM yang dimaksud adalah LKM Geometri Transformasi berbasis discovery learning dengan pendekatan kontekstual yang telah dinyatakan efektif, praktis, dan efisien. Penelitian ini merupakan penelitian deskriptif yang pengumpulan datanya menggunakan angket. Berdasarkan angket yang telah diambil terhadap 34 mahasiswa Pendidikan Matematika IKIP Budi Utomo Malang, didapatkan secara umum persepsi mahasiswa terhadap LKM berbasis discovery learning dengan pendekatan kontekstual sangat baik, menarik, dan membantu mahasiswa dalam pembelajaran Geometri Transformasi. Pada dasarnya, skor yang diperoleh berdasarkan hasil angket respons mahasiswa mencapai $80 \%$ sehingga LKM termasuk kategori sangat baik. Dengan demikian berdasarkan hasil penelitian menunjukkan bahwa persepsi mahasiswa terhadap kehadiran LKM berbasis discovery learning dengan pendekatan kontekstual pada materi geometri transformasi direspons dengan sangat baik untuk meningkatkan proses pembelajaran yang efektif, praktis dan efisien.
\end{abstract}

Kata kunci: penafsiran, LKM, geometri transformasi, discovery learning, kontekstual

\begin{abstract}
Perception constitutes konkrit's ala interpretation and reality of each insider sees something. On this research, observed object is College Student job Sheet (LKM). LKM that intended is LKM Transformasi's Geometry gets basis discovery learning with kontekstual's approaching already been declared for effective, practical, and efficient. $\mathrm{P}$ enelitian this constitute descriptive research that its data collecting utilizes questionnaire . Base questionnaire already being taken to 34 Mathematics Education college students in IKIP Budi Utomo Malang, gotten in common college student perception for LKM to get basis discovery learning with kontekstual's approaching very good, pull, and helps college student in Transformasi's Geometry learning. Basically, acquired score bases response questionnaire result college student reach $80 \%$ so LKM comprises pretty good categories. Thus bases to usufruct research points out that college student perception to LKM'S present gets basis discovery learning with contextual's approaching on transformasi's geometry material at response excellently to increase effective learning process, practical and efficient.
\end{abstract}

Keywords: perception, LKM, Transformasi's Geometry, discovery learning, Contextual 
Sitasi: Zamzam, K. F., Napfiah, S., Anugraini, A. P. 2018. Persepsi Mahasiswa terhadap LKM Geometri Transformasi Berbasis Discovery Learning dengan Pendekatan Kontekstual. Matematika dan Pembelajaran, 6(1), 65-69.

\section{PENDAHULUAN}

Sumber informasi dalam proses pembelajaran dapat berupa dosen, guru, mahasiswa, bahan bacaan, dan lain sebagainya. Bahan bacaan misalnya pengembangan bahan ajar. Kemp, et al (1998) mengusulkan bahwa untuk mengembangkan perangkat pembelajaran termasuk di dalamnya bahan ajar paling tidak berisikan 9 elemen sebagai berikut: (1) Identifikasi masalah-masalah instruksional pembelajaran termasuk mendesain tujuan pembelajaran, (2) Mengecek karakteristik pembelajaran yang akan direncanakan, (3) Mengidentifikasi isi materi dan analisis tugas yang berkaitan dengan tujuan pembelajaran, (4) Menyatakan tujuan pembelajaran untuk pebelajar, (5) Mengurutkan isi materi pembelajaran setiap bagian dari pembelajaran secara logis, (6) Mendesain strategi pengajaran, (7) Merancang rencana pengajaran yang akan disampaikan, (8) Mengembangkan alat evaluasi, (9) Menyeleksi sumber bahan untuk penunjang pembelajaran.

Tujuan dari pengembangan bahan ajar ini adalah untuk mengembangkan, menguji, dan memvalidasi bahan ajar geometri transformasi yang berupa lembar kerja mahasiswa (LKM) yang berbasis discovery learning dengan pendekatan konstekstual. Dalam lembar kerja mahasiswa (LKM) ini untuk pengenalan konsep diawali dengan masalah yang biasanya terkait dengan kehidupan sehari-hari. Harapannya dengan pengembangan lembar kerja mahasiswa (LKM) ini dapat mengubah proses pembelajaran yang semula berpusat pada guru menjadi berpusat pada mahasiswa. Untuk itu, perlu adanya studi untuk mengetahui bagaimana persepsi mahasiswa terhadap lembar kerja mahasiswa (LKM). Menurut Slameto (2005) persepsi merupakan penafsiran realitas dan masing-masing orang memandang dari sudut perspektif yang berbeda.

Discovery learning adalah salah satu metode yang dapat dikembangkan dalam dunia pendidikan. Discovery learning merupakan pembentukan kategori-kategori atau konsep-konsep yang dapat memungkinkan terjadinya generalisasi. Dalam aplikasi metode discovery learning, dosen bertindak sebagai pembimbing dimana mahasiswa diharapkan akan belajar secara mandiri, selain itu dosen juga berperan untuk mengarahkan kegiatankegiatan mahasiswa sesuai dengan tujuan yang diharapkan.

Penyajian bahan ajar yang berbasis discovery learning tidak disajikan dalam bentuk akhir, tetapi mahasiswa akan melakukan kegiatan untuk mendapatkan informasi, membandingkannya, mengkategorikan, menganalisis dan membuat kesimpulan. Salah satu kelebihan dengan menggunakan metode discovery learning adalah mendorong mahasiswa untuk berpikir dan merumuskan hipotesisnya sendiri, serta membantu mahasiswa untuk mengembangkan konsep-konsep dasar dan ide-ide. Menurut Gina (2016) ada beberapa tahapan dalam discovery learning yaitu: (1) observasi untuk menemukan masalah; (2) merumuskan masalah; (3) mengajukan hipotesis; (4) merencanakan pemecahan masalah melalui percobaan atau cara lain; (5) melaksanakan pengamatan dan pengumpulan data; (6) analisis data; (7) menarik kesimpulan atas kegiatan yang telah dilakukan atau 
penemuan.

Jonhson (2003) mengungkapkan bahwa pendekatan konstektual adalah pembelajaran yang bertujuan menolong siswa melihat makna didalam materi akademik dengan konteks kehidupan keseharian mereka, yaitu dengan konteks keadaan pribadi, sosial, dan budaya mereka. Hal ini artinya pembelajaran secara konstektual membuat mahasiswa mencari hubungan antara pengetahuan yang dimilikinya dengan penerapannya dalam kehidupan nyata.

Kelebihan dengan pendekatan kontekstual adalah membuat mahasiswa aktif dalam proses pembelajaran serta mampu mengembangkan kemampuan mahasiswa sesuai dengan pengalamannya. Pendekatan kontekstual ini jika dilakukan secara kelompok maka setiap mahasiswa akan mempunyai kesempatan saling memberi dan menerima pengetahuan dalam memahasi isi materi yang diberikan. Selain itu, pendekatan kontekstual juga membuat mahasiswa aktif untuk mencari penyelesaian atas permasalahan yang diberikan dengan nyaman, serta berusaha memeriksa, mencari, dan menyimpulkan secara logis, analitis, dan sistematis. Cara ini diharapkan dapat mendorong mahasiswa untuk mengembangkan penalaran dan berpikir kreatif untuk mengkonstruksi pengetahuannya secara mandiri.

\section{METODE}

Penelitian ini merupakan penelitian deskriptif yaitu pengumpulan datanya menggunakan angket. Objek penelitian yang diteliti adalah persepsi mahasiswa terhadap lembar kerja mahasiswa (LKM) berbasis discovery learning dengan pendekatan kontekstual. Subyek penelitian ini adalah mahasiswa program studi pendidikan matematika yang menempuh mata kuliah discovery learning. Analisis data disajikan dalam distribusi persentase (\%).

\section{HASIL DAN PEMBAHASAN}

Pengisian angket dilakukan oleh mahasiswa dengan jumlah mahasiswa sebanyak 34 mahasiswa. Adapun hasil dari rekap angket mahasiswa adalah sebagai berikut:

Tabel 1. Rekap Hasil Angket Mahasiswa

\begin{tabular}{|l|l|l|l|}
\hline No. & Aspek yang Dinilai & Ya & Tidak \\
\hline & Isi yang Disajikan & $88.24 \%$ & $11.76 \%$ \\
\hline 1 & Menampilkan masalah yang kontekstual & $88.24 \%$ & $11.76 \%$ \\
\hline 2 & $\begin{array}{l}\text { Situasi yang ditampilkan memberikan stimulus atau } \\
\text { rangsangan untuk mengidentifikasi konsep geometri } \\
\text { transformasi }\end{array}$ & $\begin{array}{l}\text { Masalah atau situasi yang ditampilkan mendorong untuk } \\
\text { mencari informasi yang berkaitan dengan konsep geometri } \\
\text { transformasi }\end{array}$ & $79.41 \%$ \\
\hline
\end{tabular}




\begin{tabular}{|l|l|l|l|}
\hline 4 & $\begin{array}{l}\text { Terdapat aktivitas agar mengolah informasi yang diperoleh } \\
\text { untuk membentuk konsep baru }\end{array}$ & $79.41 \%$ & $20.59 \%$ \\
\hline 5 & $\begin{array}{l}\text { Terdapat instruksi atau pernyataan agar memeriksa konsep } \\
\text { yang telah ditentukan }\end{array}$ & $83.82 \%$ & $16.18 \%$ \\
\hline 6 & $\begin{array}{l}\text { Terdapat instruksi agar menyimpulkan suatu konsep } \\
\text { geometri transformasi }\end{array}$ & $82.35 \%$ & $17.65 \%$ \\
\hline 7 & LKM disajikan secara sistematis & $86.76 \%$ & $13.24 \%$ \\
\hline & Bahasa & $80.88 \%$ & $19.12 \%$ \\
\hline 8 & Saya mudah memahami arahan atau petunjuk dalam LKM \\
\hline 9 & $\begin{array}{l}\text { Kalimat yang digunakan tidak ambigu, jelas, dan mudah } \\
\text { dipahami }\end{array}$ & $80.88 \%$ & $19.12 \%$ \\
\hline 10 & Pertanyaan dalam LKM jelas dan mudah saya pahami & $86.0 \%$ & $14 \%$ \\
\hline
\end{tabular}

Berdasarkan rekap angket yang dilakukan oleh 34 mahasiswa IKIP Budi Utomo Malang didapatkan secara umum persepsi mahasiswa terhadap LKM berbasis discovery learning dengan pendekatan kontekstual sangat baik, menarik, dan membantu mahasiswa dalam pembelajaran Geometri Transformasi. Pada dasarnya $80 \%$ jawaban mahasiswa menjawab iya maka masuk dalam kategori sangat baik, akan tetapi perlu adanya perubahan untuk menyempurnakan LKM.

Berdasarkan pada tabel 1 terdapat beberapa pertanyaan yang dikategorikan baik yaitu terkait dengan pertanyaan "Masalah atau situasi yang ditampilkan mendorong untuk mencari informasi yang berkaitan dengan konsep geometri transformasi" dan "Terdapat aktivitas agar mengolah informasi yang diperoleh untuk membentuk konsep baru". Intinya mahasiswa masih ada kesulitan dalam memahami konsep geometri transformasi, mereka kesulitan dalam mengaitkan informasi yang pernah didapatkan dengan konsep geometri trnasformasi sehingga konsep baru yang terbentuk kurang maksimal.

Analisis tentang persepsi mahasiswa berdasarkan tabel 1 tentang penggunaan LKM berbasis discovery learning dengan pendekatan kontekstual dapat dikategorikan menjadi tiga konsep dasar, antara lain sebagai berikut: 1. Dalam proses pembelajaran, mahasiswa menerima LKM geometri transformasi untuk meningkatkan suasana belajar yang efektif. Akan tetapi dengan adanya nilai tidak pada kategori pertanyaan nomor 7, 8, dan 9 menunjukkan tidak sepenuhnya mahasiswa mampu menerima LKM dalam menciptakan suasana belajar yang efektif. 2. Kehadiran LKM berbasis discovery learning dengan pendekatan kontekstual mampu meningkatkan pemahaman konsep geometri transformasi. Cukup tingginya nilai tidak pada kategori pertanyaan 4 dan 5 menunjukkan bahwa tidak sepenuhnya mahasiswa mampu memahami konsep geometri transformasi. 3 . Implementasi LKM dalam proses pembelajaran sangat besar. Hal ini terlihat pada indikator pertanyaan nomor 2 dan 7. Akan tetapi masih adanya mahasiswa yang menjawab tidak menunjukkan masih belum sepenuhnya diterima oleh mahasiswa implementasi LKM dalam proses pembelajaran geometri transformasi.

Salah satu penyebab yang menyebabkan tidak sepenuhnya mahasiswa mampu menerima kehadiran LKM dalam proses pembelajaran geometri transformasi adalah banyaknya mahasiswa yang berasal dari luar daerah masih kurang mampu menerima LKM dalam proses pembelajaran karena paradigma yang sudah tertanam adalah materi 
dijelaskan secara detail oleh dosen sedangkan pada LKM materi diperoleh dengan bantuan kegiatan-kegiatan yang membantu untuk mengkonstruksi sendiri konsep yang didapat sebelumnya untuk menciptakan konsep baru. Apabila dibandingkan dengan pembelajaran yang konvensional maka LKM mampu menciptakan kegiatan pembelajaran yang efektif. Oleh sebab itu pengembangan LKM berbasis discovery learning dengan pendekatan kontekstual pada materi geometri transformasi perlu dilakukan untuk meningkatkan proses pembelajaran yang efektif, praktis dan efisien.

\section{KESIMPULAN DAN SARAN}

Berdasarkan hasil penelitian menunjukkan bahwa persepsi mahasiswa terhadap kehadiran LKM berbasis discovery learning dengan pendekatan kontekstual pada materi geometri transformasi direspons dengan sangat baik untuk meningkatkan proses pembelajaran yang efektif, praktis dan efisien. Berdasarkan kesimpulan yang diperoleh, saran yang dapat diberikan yaitu bahan ajar dengan metode discovery learning dan kontekstual sebaiknya juga diterapkan pada mata kuliah selain Geometri Transformasi.

\section{DAFTAR RUJUKAN}

Gina Rosarina, Ali Sudin, Atep Sujana. (2016). Penerapan Model Discovery Learning untuk Meningkatkan Hasil Belajar Siswa pada Materi Perubahan Wujud Benda. Jurnal Pena Ilmiah Vol. 1, No. 1.

Johnson, D.W., Johnson, R.T. \& Johnson Holubec, E.J. (2003). Cooperation in the Classroom. Bandung: Alfabeta.

Slameto. (2005). Belajar dan Faktor-Faktor yang Mempengaruhinya. Jakarta: Rineka Cipta. 